University of Nebraska - Lincoln

DigitalCommons@University of Nebraska - Lincoln

Faculty Publications from the Harold W. Manter Laboratory of Parasitology

10-1977

\title{
Marine Aspidogastrids (Trematoda) from Fishes in the Northern Gulf of Mexico
}

Sherman S. Hendrix

Gettysburg College, shendrix@gettysburg.edu

Robin M. Overstreet

Gulf Coast Research Laboratory, robin.overstreet@usm.edu

Follow this and additional works at: https://digitalcommons.unl.edu/parasitologyfacpubs

Part of the Parasitology Commons

Hendrix, Sherman S. and Overstreet, Robin M., "Marine Aspidogastrids (Trematoda) from Fishes in the Northern Gulf of Mexico" (1977). Faculty Publications from the Harold W. Manter Laboratory of Parasitology. 487.

https://digitalcommons.unl.edu/parasitologyfacpubs/487

This Article is brought to you for free and open access by the Parasitology, Harold W. Manter Laboratory of at DigitalCommons@University of Nebraska - Lincoln. It has been accepted for inclusion in Faculty Publications from the Harold W. Manter Laboratory of Parasitology by an authorized administrator of DigitalCommons@University of Nebraska - Lincoln. 


\title{
MARINE ASPIDOGASTRIDS (TREMATODA) FROM FISHES IN THE NORTHERN GULF OF MEXICO*
}

\author{
Sherman S. Hendrix $\dagger$ and Robin M. Overstreet
}

ABSTRACT: Of the aspidogastrids Multicalyx cristata, Lobatostoma ringens, Cotylogaster basiri, and C. dinosoides sp. n., the last two had not been previously known from the Gulf of Mexico. The latter differs from other members of its genus by having relatively large equatorial marginal alveoli in comparison to those at the anterior and posterior ends of the holdfast. It also possesses extensive transverse musculature connecting opposed lateral alveoli. New host records are included for all four species, and we report preadults of what appear to be the first two species.

Trematodes belonging to the family Aspidogastridae Poche 1907 infect marine and estuarine fishes, but few reports document the relatively common occurrence of these worms in the Gulf of Mexico. Of the four we found in Mississippi and adjacent areas, one is new and one other had never been reported from the Gulf.

Described material was removed fresh from the hosts and fixed with hot AFA solution under minimal coverslip pressure. Totomounts were stained with Van Cleave's hematoxylin or rarely with Semichon's carmine and sections with Harris' or Heidenhain's iron hematoxylin, often with eosin. Figures were drawn with the aid of a camera lucida; measurements are in micrometers unless stated otherwise.

\section{Cotylogaster basiri Siddiqi and Cable 1960 (Figs. 1, 2, 5, 6)}

Redescription (based on 15 whole mounts, 2 sectioned later; values for holotype in parentheses): Body 1,554 to $7,336(4,650)$ long by 870 to 2,278 $(1,871)$ at widest level of ventral holdfast. Ventral holdfast organ 1,451 to 4,007 (3,530) long, occupying all of ventral surface of body excluding neck and "tail" (= terminal muscular dorsal cone), possessing one continuous marginal row of 60 to 66 (56) cuplike alveoli and medial row of 19 to 23

Received for publication 28 January 1977.

* This study was conducted in cooperation with the U.S. Department of Commerce, NOAA, National Marine Fisheries Service, under PL 88-309, Project No. 2-262-R and NOAA, Office of Sea Grant, under Grant No. 04-6-158-44060. The U.S. Government is authorized to produce and distribute reprints for governmental purposes notwithstanding any copyright notation that may appear hereon.

$\dagger$ Department of Biology, Gettysburg College, Gettysburg, Pennsylvania 17325.

\$ Gulf Coast Research Laboratory, Ocean Springs, Mississippi 39564.
(19) elongate transverse alveoli, with prominent marginal organs and papillae on alveolar ridges; marginal alveoli supplied with glandular cells. Neck retractile, bearing conspicuous flange near base allowing neck to retract, terminating with buccal disc; disc displaying 1 dorsal, 2 lateral, and 2 ventrolateral lobes under appropriate fixation; dorsal lobe acutely pointed when not inverted and forming cleft. Tail retractile, with ratio of portion extended beyond holdfast to holdfast-length $1: 3$ to 53 depending on length of worm and state of contraction; well-contracted and not extended beyond holdfast in holotype. Tegument aspinose. Eyespots pigmented, 5 to 19 (dispersed) long by 3 to 12 (dispersed) wide when compacted, often diffuse especially in large individuals. Ring of prominent outer longitudinal and inner circular muscles compartmentalizing alimentary and reproductive organs from level of approximately midneck to postequatorial level; less dense musculature extending to near tip of tail. Groups of cells underlying dorsal anucleate tegument. Prepharynx 195 to 494 (255) long. Pharynx 180 to 465 (299) long by 93 to 255 (223) wide; anterior $1 / 4$ to $1 / 3$ with dense concentric circular muscle fibers; central area of posterior portion filled with nucleated cells. Esophagus nonepithelialized, short, indistinct when contracted. Cecum a simple epithelialized sac; termination variable within gonadal level; posterior portion in atypical specimen with 1 simple and 1 bilobed pedunculated outpouching.

Testes 2, tandem to diagonal, rarely symmetrical, usually separated from each other, postequatorial; anterior testis 105 to 806 (339) long by 135 to 488 (235) wide; posterior testis usually sinistral to anterior one when diagonal, 128 to 626 (335) long by 102 to 603 (273) wide. Seminal vesicle sinuous, often swollen at ends or elsewhere. Prostatic vesicle elongate, 263 to 742 ( 568 ) long by 49 to 322 (145) wide, lined internally with membrane-bound anucleate bodies, surrounded externally by conspicuous layer of prostatic cells approximating width of vesicle. Cirrus and cirrus sac lacking. Ejaculatory duct and variably-shaped genital atrium surrounded by glandular cells. Genital pore median, usually immediately posterior to forward margin of holdfast organ, opening into defined cavity external to compartmentalizing musculature but internal to holdfast organ or tegument at neck 
level in extended specimens; cavity widening anteriorly, opening to environment at or immediately anterior to forward margin of holdfast, regulated by contraction of flange.

Ovary anteriomedial and often contiguous to anterior testis, smooth, 132 to 546 (342) long by 75 to 425 (220) wide. Laurer's canal passing dorsally along less dense extension of muscular compartmentalization and opening to surface subterminally and dorsally near posterior tip of tail. Seminal receptacle of uterine type. Ootype usually adjacent to ovary, relatively small. Oviduct recurved. Vitelline reservoir usually posterior to ootype, receiving 2 vitelline ducts laterally from continuous or occasionally interrupted inverted Ushaped band of follicles; posterior level of band lying within testicular level, less extensive in holotype since right branch extending to ovarian level and left one anterior to that; anterior level variable; follicles 21 to 165 long by 15 to 90 wide. Uterus voluminous in large specimens, extending anteriorly to anterior loop of vitellaria and occasionally as far anterior as midlevel of prostatic complex, occupying most of posterior $1 / 2$ of worm including tail; metraterm muscular, usually wider distally than proximally, longer than prostatic vesicle, sinistral to prostatic complex, usually entering genital atrium at same level as ejaculatory duct, surrounded by glandular cells occurring most conspicuously at distal end. Eggs numerous, 53 to 78 long by 27 to 41 wide, containing biocellate larvae; larvae often hatching within uterus.

Excretory system bivesiculate; collecting tubules recurving posteriorly near anterior of buccal disc; pore terminal or dorsal and subterminal depending on state of contraction of tail; both vesicles emptying into tegumental cavity at same point as opening of Laurer's canal, surrounded distally by numerous compacted cells.

New host records: Archosargus probatocephalus (Walbaum), sheepshead, Sparidae; Micropogonias undulatus (Linnaeus), Atlantic croaker, Sciaenidae; Menticirrhus americanus (Linnaeus), southern kingfish, Sciaenidae; Trachinotus carolinus (Linnaeus), Florida pompano, Carangidae; $T$, falcatus (Linnaeus), permit, Carangidae.

Sites: Intestine and rectum.

Localities: Mississippi and Louisiana.

Specimen deposited: USNM Helm. Coll. No. 74462.

\section{DISCUSSION}

Siddiqi and Cable (1960) originally described Cotylogaster basiri on the basis of three specimens. Isseroff and Cable (1968) added a notation on the larva and its eyespots. With our additional specimens we have supplemented the species' description considerably as well as extended the ranges for measurements and corrected a few minor measurements. Two important corrections to the original description are that a true cirrus sac is lacking, a point already made by Fredericksen (1972), and that the excretory system is bivesiculate rather than having an I-shaped bladder. Depending on the contraction of the tail, the vesicles open separately or into an invagination at the tip, giving the appearance of a V-shaped bladder.

An important feature of $C$. basiri and all other species of Cotylogaster Monticelli 1892 is the cylindrical circular and longitudinal muscle layers that encircle much of the alimentary tract and reproductive system (Figs. 5, 6). Most aspidogastrids possess a transverse septum that divides the dorsal portion containing the alimentary tract and terminal genitalia from a ventral portion containing the gonads. Cylindrical compartmentalization differs among species as will be seen in the following species having gonads external to the compartment.

All the listed hosts represent new records. Previously, the parasite was known only from the porgies Calamus calamus (Valenciennes) and C. bajonado (Bloch and Schneider). Those infections occurred in Puerto Rico (Siddiqi and Cable, 1960) and Jamaica (Nahhas and Cable, 1964). Thus, our records extend the parasite's geographical range to the northern Gulf of Mexico.

Based on the presence of both small preadult and large mature specimens in fish, the largest being in fish well offshore, we assume fish normally aid in completing the life history of the worm and that the worm grows in fish. Specific fish apparently act only as faculative hosts for C. occidentalis Nickerson 1902. Dickerman (1948) was able to establish worms from snails in only one of two challenged fish. He reported that large worms from snails contained eggs, and Wootton (1966) presented preliminary data on infecting bivalves experimentally with larvae hatched from bivalveworms. However, as pointed out by Cable (1974), few specimens of C. occidentalis in a species of snail studied by him for more than 30 years possessed eggs, and no eggs or larvae ever occurred in dishes with isolated snails.

Cotylogaster presently includes four species, C. michaelis Monticelli 1892, the type-species, C. occidentalis, C. basiri, and C. barrowi Huehner and Etges 1972, but Fredericksen (1972) considered the latter a synonym of $C$. occidentalis. We found immature specimens of another 

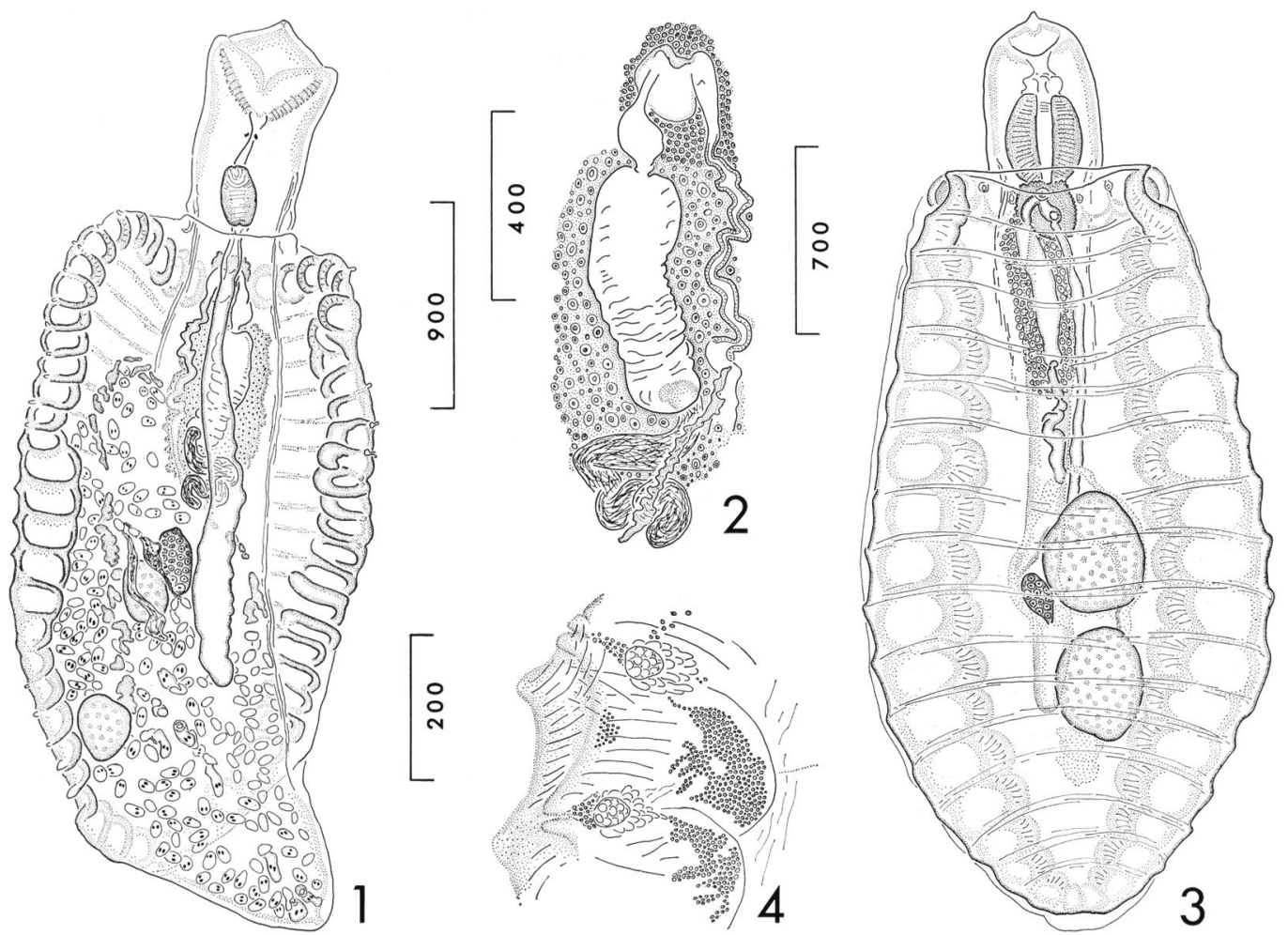

Figures 1-4. Aspidogastrids from the Gulf of Mexico; 1, 2. Cotylogaster basiri from Micropogonias undulatus. 1. Whole mount, dorsal view. 2. Terminal genitalia, ventral view. 3. Cotylogaster dinosoides from Pogonias cromis, holotype, ventral view. 4. Multicalyx cristata from Pristis pectinata, marginal organ, lateral view.

species, and, because they clearly represent a distinct species and most characters are evident, we describe it below.

\section{Cotylogaster dinosoides sp. n.} (Figs. 3, 7)

Description (based on 5 immature whole mounts, 1 subsequently sectioned): Body 2,721 to 3,492 long. Ventral holdfast 2,226 to 2,837 long by 1,104 to 1,580 wide, occupying ventral surface of entire body excluding neck and posterior extension, possessing one continuous marginal row of 40 to 42 cuplike alveoli and medial row of 17 elongate transverse alveoli; marginal organs distinct on alveolar ridges with associated papillae short and inconspicuous; marginal alveoli relatively large near equator of worm compared with progressively smaller ones anteriorly and posteriorly, supplied with glandular cells; posterior extension up to $2 \%$ of body length; neck retractile, bearing inconspicuous flange near base allowing neck to retract, terminating as simple retractile buccal funnel possessing no lateral lobes but single acutelypointed retractile dorsal lobe. Eyespots with pig- ment lacking. Tegument having dense, filamentous, anucleated, aspinose portion occasionally over 15 thick; underlain by distinct parenchymal layer supporting groups of nucleated cells or cell portions associated with external layer by ducts; parenchymal layer overlying basal lamina followed by longitudinal muscle bundles, parenchymal cells, and extensive transverse fibers connecting marginal alveoli. Ring of prominent outer longitudinal and inner circular muscles compartmentalizing alimentary tract and most of terminal genitalia but not gonads, extending between midpharyngeal level and immediately beyond testes where muscles becoming diffused. Prepharynx muscular, variable, 54 to 128 , capable of forming lips, ventral to prominent transverse commissure of nervous system. Pharynx 263 to 339 long by 216 to 275 wide; anterior $1 / 6$ to $1 / 4$ with dense concentric circular muscle fibers; central area of posterior portion filled with nucleated cells. Esophagus nonepithelialized, short and indistinct when contracted. Cecum a simple epithelialized sac, extending posteriorly to between 23 and $30 \%$ of body length from posterior end.

Testes 2 , postequatorial, usually tandem but occasionally diagonal, rarely contiguous; anterior 


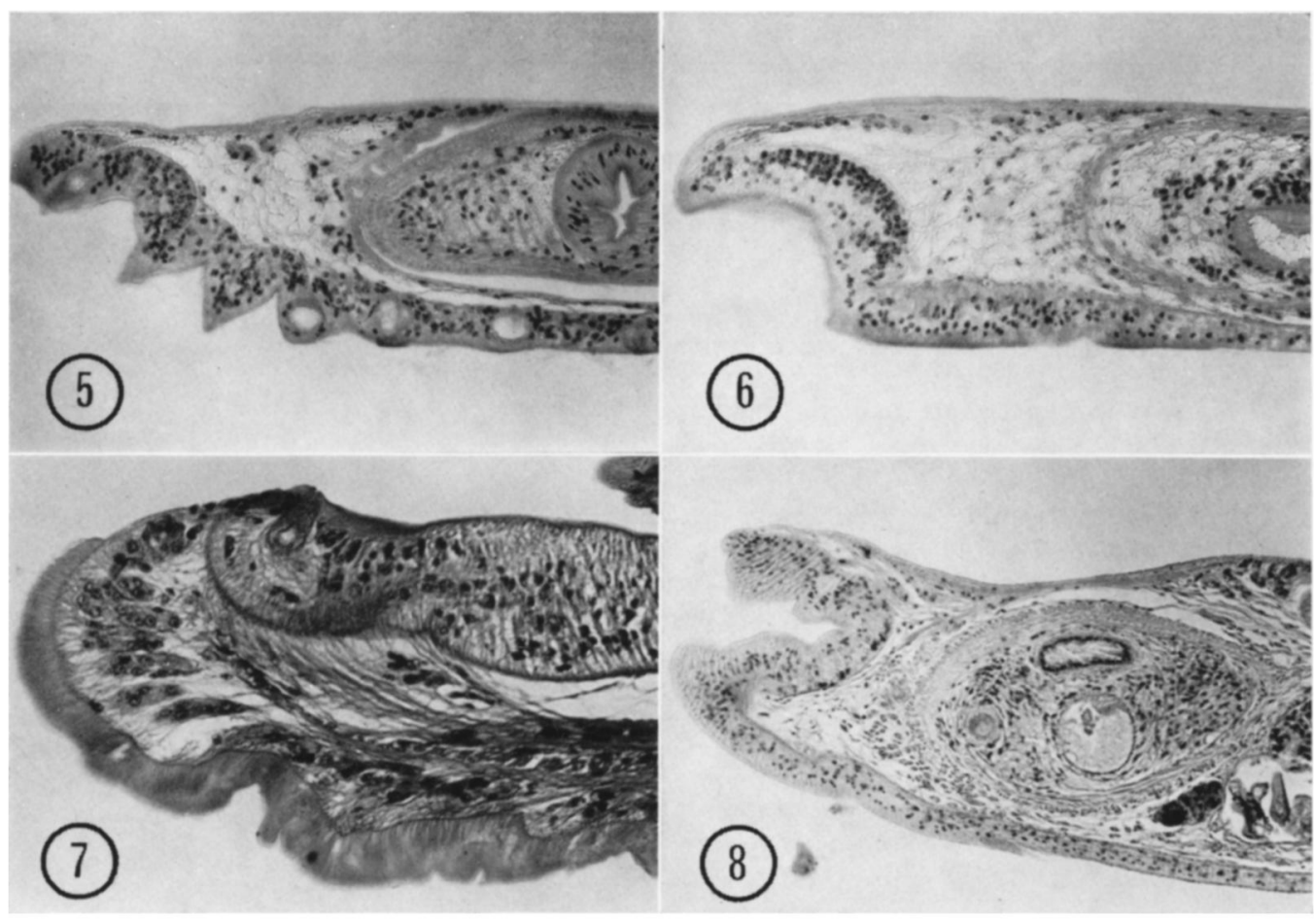

Figures 5-8. Cross-sections of aspidogastrids; 5, 6. Cotylogaster basiri. 5. Section at pharyngeal level near anterior margin of ventral holdfast; note prominent musculature separating neck from body proper, Heidenhain's iron hematoxylin, $\times 206$. 6. Section at level of prostatic vesicle (next to narrow cecum); note that musculature is less well developed than in Fig. 5 but still easily visible, Heidenhain's iron hematoxylin, $\times 173$. 7. Cotylogaster dinosoides, alveolus of twisted worm showing marginal organ and peripheral aspect of attached transverse musculature, Heidenhain's iron hematoxylin, $\times 166$. 8. Lobatostoma ringens, section at level of prostatic vesicle; darkly stained organ in middle of worm at margin is testis, Harris' hematoxylin and eosin, $\times 106$.

testis 207 to 442 long by 154 to 367 wide; posterior testis at or anterior to termination of cecum, 217 to 413 long by 160 to 318 wide. Posttesticular space 20 to $28 \%$ of body length. Seminal vesicle sinuous, never extending as far posterior as testes at least in immature specimens; vas deferens joining vasa efferentia about midway between seminal vesicle and testes. Prostatic vesicle elongate, lined internally with membrane-bound anucleate bodies, surrounded externally by numerous prostatic cells. Cirrus and cirrus sac lacking. Ejaculatory duct relatively long, sinuous, surrounded by compact clump of glandular cells. Genital atrium approximately as long as length of underlying alveolus, surrounded by glandular cells. Genital pore approximately median, near level of anterior holdfast margin.

Ovary dextral to and either contiguous with or separated from anterior testis, 83 to 210 long by 45 to 116 wide. Laurer's canal opening dorsally near posterior of worm. Uterus looping well anterior to forward testis and coiled posterior to rear one; metraterm sinistral to prostatic complex, with distal portion surrounded by glandular cells. Eggs not present. Vitellaria anlagen having anterior follicles of inverted U-shaped loop dorsal to anterior testis in one specimen and between anterior uterine extension of coil and testis in another.

Excretory system bivesiculate; pore dorsal, subterminal, emptying into thickened tegumental cavity 8 to $13 \%$ of body length from posterior end; separate vesicles often extending posterior to pore before emptying, joining each other immediately proximal to pore and adjacent to Laurer's canal, with distal portions surrounded by compacted cells; anterior paired collecting tubules recurving posteriorly anterior and dorsal to transverse nerve commissure.

Type host: Pogonias cromis (Linnaeus), black drum, Sciaenidae.

Site: Intestine.

Locality: Marsh Point in Mississippi Sound, Ocean Springs, Mississippi.

Holotype: USNM Helm. Coll. No. 74463; paratype: No. 74464.

Etymology: The specific name dinosoides, from the Greek dinos (a drinking bowl) and oides (resembling), refers to each of the several large alveoli. 
TABLE I. Teleost host for Lobatostoma ringens.

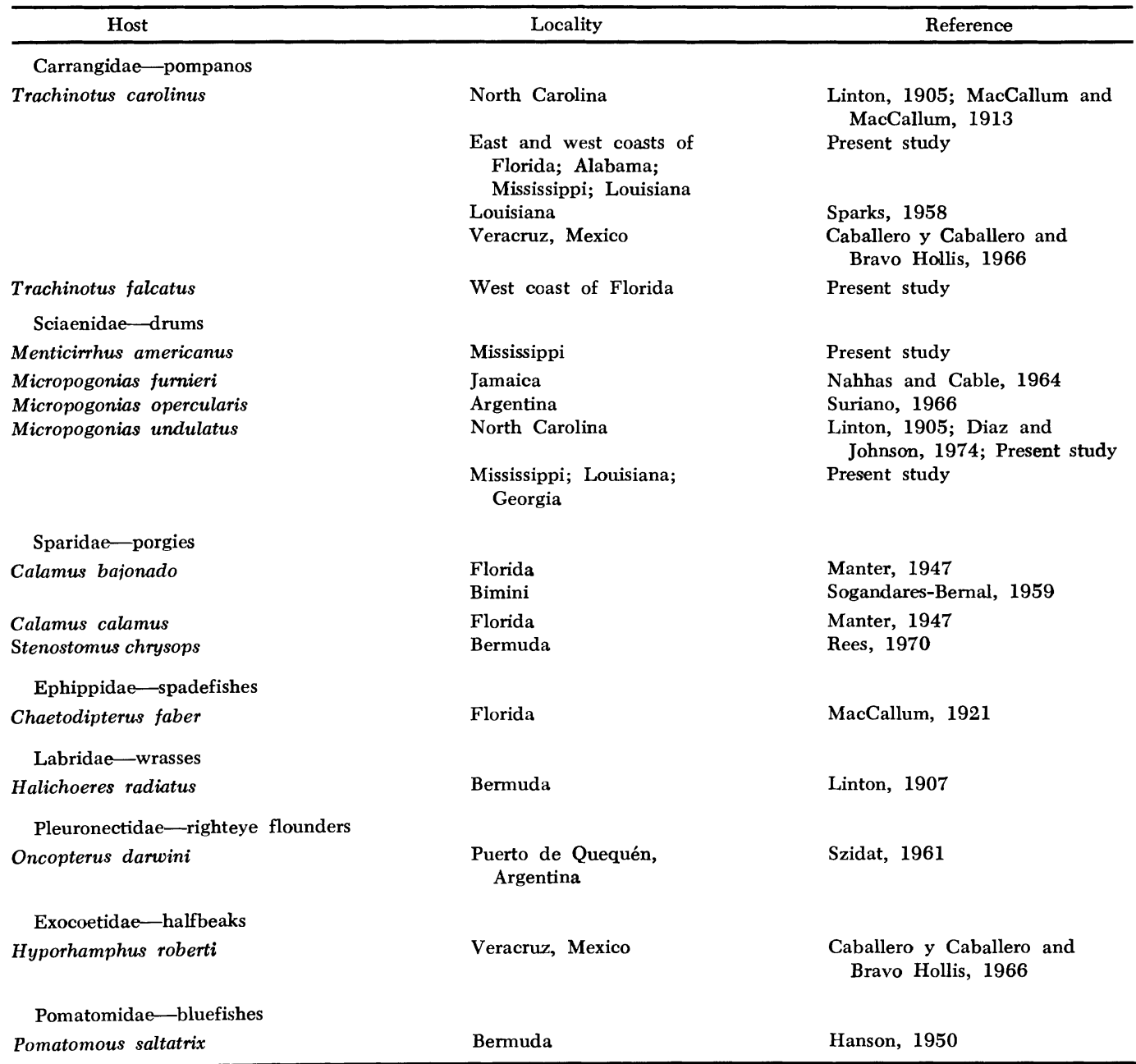

\section{DISCUSSION}

Cotylogaster dinosoides can be separated from all other members of the genus by its relatively large equatorial marginal alveoli in comparison to those alveoli at the anterior and posterior of the holdfast. It also possesses extensive transverse musculature connecting opposing lateral alveoli (Fig. 7), allowing a nearly cylindrical aspect of the living worm, as well as a simple buccal funnel without lateral lobes. The Mediterranean species, $C$. michaelis, appears to be most similar. It differs further from $C$. dinosoides by having vitelline follicles that extend anteriorly near the anterior margin of the holdfast. The sympatric $C$. basiri can be easily differentiated from $C$. dinosoides because the preadult and short adult, as well as the larva, have conspicuous eyespots and because its gonads occur in the cylindrical muscular compartment. Cotylogaster occidentalis, a freshwater species, has been reported from the freshwater drum in nearby Lake Pontchartrain in Louisiana (Sogandares-Bernal, 1955), which is brackish in areas; the elongated adult possesses 79 to 273 marginal alveoli, but even when fewer alveoli occur in immature specimens, alveoli are all similar in size.

\section{Lobatostoma ringens (Linton 1907)} (Fig. 8)

Teleost hosts and their localities: See Table I.

New molluscan host: Donax roemeri protracta Conrad, coquina. 
Localities of clam: Horn Island, Mississippi; Alabama Point, Baldwin County, Alabama.

Specimens deposited: USNM Helm. Coll. Nos. 74465-74466.

\section{DISCUSSION}

Lobatostoma ringens has been reported more often than any other marine aspidogastrid. Table I lists those records as well as our findings. The worm has been adequately described for most features, most recently by Caballero y Caballero and Bravo Hollis (1966). Its range extends from at least North Carolina to Argentina.

Some of the musculature of $L$. ringens and of species of Cotylogaster show similarities and differences. A thick cylindrical ring extends to near the worm's posterior end and encircles the alimentary tract and terminal genitalia, but not the gonads (Fig. 8). This feature is thinner and not cylindrical in cross-sections of L. manteri Rohde 1973 illustrated by Rohde (1973) and Rohde and Sandland (1973). Rather than having dense fibers traversing the dorsal portion of the body as in Cotylogaster dinosoides, $L$. ringens possesses a dense concentration of attached fibers along most of the dorsal midline. These attached fibers, rather than conspicuously extending to the marginal alveoli as the unattached transverse ones do in $C$. dinosoides, spread out with the majority attaching along the lateral portions of the medial alveoli. The groups of cells which in $C$. dinosoides primarily occur confined to a parenchymal layer subjacent to the anucleate tegument exist, but not in such a band and often ventral to the transverse muscle fibers. Anterior concentric circular muscles of the pharynx occur just as in L. manteri and the two species of Cotylogaster described here.

Lobatostoma ringens probably requires a teleost to complete its life cycle. Preadult and small adult specimens occurred frequently in Florida pompano feeding on the clam Donax roemeri protracta. An immature specimen occurred in 1 of 865 clams examined from Mississippi and another in 1 of 50 from Alabama. Both locations consist of high-energy, highsalinity beaches bordering the Gulf of Mexico. Hopkins (1958) reported Lobatostoma sp. from D. variabilis in Texas, and Sparks (1960) considered that worm to be $L$. ringens. The clam's identity is actually $D$. roemeri roemeri Philippi.

Rohde (1973) found no specimens of $L$. manteri with eggs in snails. He was unable, except for limited doubtful success, to infect a sea turtle or fishes other than Trachinotus blochi (Lacépède) with adult or preadult specimens. That fish, related to the pompanos hosting L. ringens, L. kemostoma (MacCallum and MacCallum 1913), and L. pacificum Manter 1940 , presumably represents the primary vertebrate host of the two-host cycle. According to Szidat (1970), an immature specimen of $L$. pacificum infected a snail from freshwater in Rio de la Plata, Argentina.

\section{Multicalyx cristata (Faust and Tang 1936) (Fig. 4)}

New host records: Pristis pectinata Latham, smalltooth sawfish, Pristidae; Dasyatis sayi (Leseur) bluntnose stingray, Dasyatidae; Cephaloscyllium ventriosum (Garman), swell shark, Scyliorhinidae.

Site: Bile ducts.

Localities: Off Mississippi in Gulf of Mexico and Santa Barbara, California.

Specimens deposited: USNM Helm. Coll. No. 74467 ( 2 slides).

\section{DISCUSSION}

Our specimens, 28 to $101 \mathrm{~mm}$ in length, compare favorably with descriptions and supplemental data (Faust and Tang, 1936; Dollfus, 1958a, b; Stunkard, 1962). Additionally, they possess marginal organs like other aspidogastrids (Fig. 4). These organs associate with short broad papillae on lateral ridges between individual alveoli and extend from the anterior alveolus to those preceding incompletely developed alveoli near the posterior end; they also occur in the holotype.

Extremely striking in appearance, living worms have reddish alveoli contrasting with a pale yellow body proper. Even though we found the worms residing in the bile duct, conspicuously operculated eggs 116 to 128 long by 73 to 78 wide with well-developed typical aspidogastrid larvae occurred attached to the epithelium of the gall bladder. Stunkard and Dollfus both cited the gall bladder as the location of adults in their reports. Faust and Tang (1936) originally described it from a single worm listed from the spiral valve, but we agree with Stunkard (1962) in questioning that site. 
All three hosts that we report represent new records. The presence of $M$. cristata in Cephaloscyllium ventriosum from Santa Barbara, California, extends the range to the Pacific Ocean. Stunkard (1962) stated, "Dr. Laurie reported (in littoris) that according to Dr. James E. Lynch, 'Macraspis is fairly abundant in the ratfish (Hydrologus colliei) in Puget Sound.' " Examination of Lynch's specimens in the U.S. National Museum, however, reveals them to be Taeniocotyle elegans (Olsson 1869). Previously, Faust and Tang (1936) reported M. cristata from Rhinoptera bonasus (Mitchill) (= R. quadriloba) in Mississippi; Stunkard (1962) reported it from Dasyatis centroura (Mitchill) in Massachusetts; and Dollfus (1958a) reported it from Mustelus canis (Mitchill), Rhizoprionodon (= Scoliodon) terraenovae (Richardson), and Rhinobatos cemiculus (St. Hilaire) in Senegal, in western Africa.

We encountered immature aspidogastrids from the gall bladder of the checkered puffer, Sphoeroides testudineus (Linnaeus) (in Biscayne Bay, Florida), and from the intestine of Menticirrhus americanus (off Horn Island, Mississippi) (deposited as USNM Helm. Coll. Nos. 74468-74469) that are most likely $M$. cristata. Manter (1931) also reported an immature aspidogastrid from the intestine of $M$. americanus, but considered it as possibly Taeniocotyle (= Macraspis) elegans. Whether our specimens are immature $M$. cristata and whether the fishes represent accidental or transfer hosts remain uncertain. Most of the diverse elasmobranch hosts, however, do feed on teleosts.

Some nomenclatural problems have involved M. cristata. Faust and Tang (1936) erected Multicalyx as a subgenus of Stichocotyle Cunningham 1884 when describing the species. Since then, the species usually had been considered Macraspis cristata following Manter's (1954) transfer, until Stunkard (1962) pointed out that Macraspis Olsson 1869 was preoccupied by Macraspis MacLeay 1819, an insect, and resurrected Multicalyx with $M$. cristata as the type species; he created Taeniocotyle for $M$. elegans, which he considered generically different. Both species probably belong to the same genus, but that problem will not be treated here.

\section{ACKNOWLEDGMENTS}

We are grateful to F. G. Hochberg, Jr., Charles E. Brown, John H. Finucane, Tom Mattis, and Marine Life, Inc. of Gulfport, Mississippi, for donating or loaning aspidogastrids or unexamined hosts. Ralph Lichtenfels allowed us to examine material from the Beltsville Parasitological Laboratory of the U.S. National Museum, and Ronnie G. Palmer, Edward C. Whatley, Jr., and Ann St. Andrie provided technical assistance.

\section{LITERATURE CITED}

Caballero y Caballero, E., and M. Bravo Hollis. 1966. Trematoda Rudolphi, 1808 de peces marinos del litoral mexicano del Golfo de México y del Mar Caribe. I. Rev Biol Trop 13: 297-301.

Cable, R. M. 1974. Phylogeny and taxonomy of trematodes with reference to marine species. In W. B. Vernberg (ed.), Symbiosis in the Sea. University of South Carolina Press, Columbia, South Carolina, p. 173-193.

Diaz, A., And C. A. Johnson, III. 1974. The effect of season and salinity on the distribution of parasites of estuarine fishes from North Carolina. ASB Bull 21: 15.

Dickerman, E. E. 1948. On the life cycle and systematic position of the aspidogastrid trematode, Cotylogaster occidentalis Nickerson, 1902. J Parasitol 34: 164.

Dollfus, R. Ph. 1958a. Sur Macraspis cristata (E.-C. Faust et C.-C Tang 1936) H.-W. Manter 1936 et sur une emendation nécessaire a ma définition de la famille des Aspidogastridae (Trematoda). Ann Parasitol Hum Comp 33 : 227-231.

1958b. Cours d'helminthologie. I.Trematodes sous-classe Aspidogastrea. Ann Parasitol Hum Comp 33 : 305-395.

Faust, E. C., ANd C.-C. TANG. 1936. Notes on new aspidogastrid species, with a consideration of the phylogeny of the group. Parasitology 28: 487-501.

Frederucksen, D. W. 1972. Morphology and taxonomy of Cotylogaster occidentalis (Trematoda: Aspidogastridae). J Parasitol 58: 1110 1116.

Hanson, M. L. 1950. Some digenetic trematodes of marine fishes of Bermuda. Proc Helminthol Soc Wash 17: 74-89.

Hopkins, S. H. 1958. Trematode parasites of Donax variabilis at Mustang Island, Texas. Publ Inst Mar Sci, Univ Tex 5: 301-311.

Isseroff, H., AND R. M. CABle. 1968. Fine structure of photoreceptors in larval trematodes. A comparative study. Z Zellforsch Mikrosk Anat 86: 511-534.

Linton, E. 1905. Parasites of fishes of Beaufort, 
North Carolina. Bull U S Fish Comm (1904) 24: $321-428$.

1907. Notes on parasites of Bermuda fishes. Proc U S Nat Mus 33: 85-126.

MacCallum, G. A. 1921. Studies in helminthology. Part 1. Trematodes. Part 2. Cestodes. Part 3. Nematodes. Zoopathologica 1: 135-284.

- AND W. G. MacCallum. 1913. On Aspidogaster ringens (Linton) and A. kemostoma n. sp. Zool Jahrb Abt Syst Oekl Geogr Tiere, Jena 34: 245-256.

Manter, H. W. 1931. Some digenetic trematodes of marine fishes of Beaufort, North Carolina. Parasitology 23 : 396-411.

- 1947. The digenetic trematodes of marine fishes of Tortugas, Florida. Am Midl Nat 38: $257-416$.

1954. Some digenetic trematodes from fishes of New Zealand. Trans $R$ Soc $N$ Z 82 : 475-568.

Nahras, F. M., and R. M. Cable. 1964. Digenetic and aspidogastrid trematodes from marine fishes of Curacao and Jamaica. Tulane Stud Zool Bot 11 : 169-228.

ReEs, G. 1970. Some helminth parasites of fishes of Bermuda and an account of the attachment organ of Alcicornis carangis MacCallum, 1917 (Digenea: Bucephalidae). Parasitology 60: 195-221.

RoHDE, K. 1973. Structure and development of Lobatostoma manteri sp. nov. (Trematoda: Aspidogastrea) from the Great Barrier Reef, Australia. Parasitology 66: 63-83.

—, AND R. SANDLAND. 1973. Host-parasite relations in Lobatostoma manteri Rohde (Trematoda: Aspidogastrea). Z Parasitenkd 42 : 115-136.

Siddiqu, A. H., ANd R. M. Cable. 1960. Digenetic trematodes of marine fishes of Puerto
Rico. Sci Surv Porto Rico and Virgin Islands 17: 257-369.

Sogandares-Bernal, F. 1955. Some helminth parasites of fresh and brackish water fishes from Louisiana and Panama. J Parasitol 41: 587-594.

- 1959. Digenetic trematodes of marine fishes from the Gulf of Panama and Bimini, British West Indies. Tulane Stud Zool Bot 7: 71-117.

Sparks, A. K. 1958. Some digenetic trematodes of fishes of Grand Isle, Louisiana. Proc La Acad Sci 20: 71-82.

- 1960. Some aspects of the zoogeography of the digenetic trematodes of shallow-water fishes of the Gulf of Mexico. Lib Hom E. Caballero y C.: 285-298.

Stunkard, H. W. 1962. Taeniocoytle nom. nov. for Macraspis Olsson, 1869, preoccupied, and systematic position of the Aspidobothrea. Biol Bull 122: 137-148.

Suriano, D. M. 1966. Estudio de la fauna parasitaria de Micropogon opercularis en relacion con problemas zoogeograficos del Atlantico Sur. Parasitologia 1 : $31-47$.

SzIDAT, L. 1961. Versuch einer Zoogeographie des Süd-Atlantik mit Hilfe von Leitparasiten der Meeresfische. Parasitol Schriftenr 13: $1-98$.

- 1970. [Further studies on the marine relict fauna of the Plate River system.] In $\mathrm{K}$. S. Singh and B. K. Tandan (eds.), H. D. Srivastava Commemoration Volume. Indian Veterinary Research Institute, Izatnagar, U. P., p. 637-653.

Wootron, D. M. 1966. The cotylocidium larva of Cotylogasteroides occidentalis (Nickerson, 1902 ) Yamaguti 1963 (Aspidogasteridae Aspidocotylea Trematoda). Proc 1st Int Congr Parasitol 1964: 547-548. 